\title{
Adakite-like signature of Late Miocene intrusions at the Los Pelambres giant porphyry copper deposit in the Andes of central Chile: metallogenic implications
}

Received: 12 November 2002/ Accepted: 9 May 2003/Published online: 13 September 2003

(C) Springer-Verlag 2003

\begin{abstract}
Adakite-like features are recognized in the Late Miocene $(\sim 10 \mathrm{Ma})$ porphyritic intrusions of the Los Pelambres giant porphyry copper deposit, central Chile $\left(32^{\circ} \mathrm{S}\right)$. Located within the southern portion of the flat-slab segment $\left(28-33^{\circ} \mathrm{S}\right)$ of the Chilean Andes, the Al- and Na-rich porphyries of Los Pelambres display distinctly higher $\mathrm{Sr} / \mathrm{Y} \quad(\sim 100-300)$ and $\mathrm{La}_{\mathrm{N}} / \mathrm{Yb}_{\mathrm{N}}$ $(\sim 25-60)$ ratios than contemporaneous and barren magmatic units (e.g., La Gloria pluton, Cerro Aconcagua volcanic rocks) of the same Andean magmatic belt. Strong fractionation of heavy rare earth elements (HREE), absence of Eu anomalies, high $\mathrm{Sr} / \mathrm{Y}$ and $\mathrm{Zr} / \mathrm{Sm}$ and low $\mathrm{Nb} / \mathrm{Ta}$ ratios suggest melt extraction from a garnet-amphibolite source. The Late-Miocene adakitelike porphyritic intrusions at Los Pelambres formed closely related in time and space to the subduction of the Juan Fernández Ridge (JFR) hotspot chain along the Chilean margin. Current tectonic reconstructions reveal that, at the time of formation of the Los Pelambres rocks, a W-E segment of the JFR started to subduct
\end{abstract}

Editorial handling: R.J. Goldfarb

M. Reich · M. A. Parada $(\bowtie) \cdot$ C. Palacios

Departamento de Geología,

Facultad de Ciencias Físicas y Matemáticas.,

Universidad de Chile,

Plaza Ercilla \#803,

Correo 21, 13518 Santiago,

Casilla, Chile

E-mail:maparada@cec.uchile.cl

Tel : + 56-2-6784538

Fax: + 56-2-6963050

M. Reich

Department of Geological Sciences,

University of Michigan,

2534 C.C. Little Building,

425 East University,

Ann Arbor, Mi 48109-1063, USA

A. Dietrich · F. Schultz · B. Lehmann

Institut für Mineralogie und Mineralische Rohstoffe,

Technische Universität Clausthal,

Adolph-Roemer-Str. 2a, 38678

Clausthal-Zellerfeld, Germany beneath them, producing a slow-down of a previously rapid southward migration of a NE-ridge - trench collision. These particular tectonic conditions are favorable for the origin of the Los Pelambres porphyry suite by melting of subducting young hotspot rocks under flatslab conditions. The incorporation of crustal components into the oceanic lithopheric magma source by subduction erosion is evidenced by the $\mathrm{Sr}-\mathrm{Nd}$ isotope composition of the Los Pelambres rocks different from the MORB signatures of true adakites. A close relationship apparently exists between the origin of this adakite-like magmatism and the source of the mineralization in the Los Pelambres porphyry copper deposit.

Keywords Adakites - Giant porphyry copper deposits Central Andes

\section{Introduction}

The genetic link between magmatism and porphyrycopper-style mineralization in active continental margins is well documented (Titley and Beane 1981; Hedenquist and Lowenstern 1994). Intrusion-related hydrothermal systems get their thermal energy and variable amounts of volatiles, metals and other components largely from subduction-related magmas emplaced at shallow levels of the Earth's crust (Cathles 1981; Sawkins 1990).

The Andes of central Chile host some of the world's largest porphyry copper deposits, such as El Teniente, Río Blanco-Los Bronces and Los Pelambres. These deposits were formed during the Miocene-Pliocene when both shallowing of the subduction angle and crustal thickening occurred (Skewes and Stern 1996). Skewes and Stern (1994) suggested that exsolution of copperbearing magmatic fluids responsible for brecciation, alteration and mineralization at this time was produced by a rapid decrease of lithostatic pressure.

In this paper we examine the geochemical composition and the magma sources of the porphyry intrusions associated with the mineralization at the Los Pelambres 
$\mathrm{Cu}$ deposit $\left(31^{\circ} 43^{\prime} \mathrm{S}, 70^{\circ} 29^{\prime} \mathrm{W}\right)$, located in the southern part of the Andean flat-slab segment, $190 \mathrm{~km}$ north of Santiago (Fig. 1). Previous work on the Los Pelambres deposit reported data on the age of the mineralization (e.g., Mathur et al. 2001), the nature and extent of the associated hydrothermal alteration/mineralization (Sillitoe 1973; Atkinson et al. 1996), and isotopic signatures of the fluids related to brecciation events (Skewes and Stern 1996). However, there is no information about the origin of the magmas that generated this porphyry system. For this reason we constrain geochemically the nature of its source, and propose a petrogenetic model consistent with the tectonic setting at the time of its formation. In order to put the Los Pelambres rocks in a more regional context, a geochemical

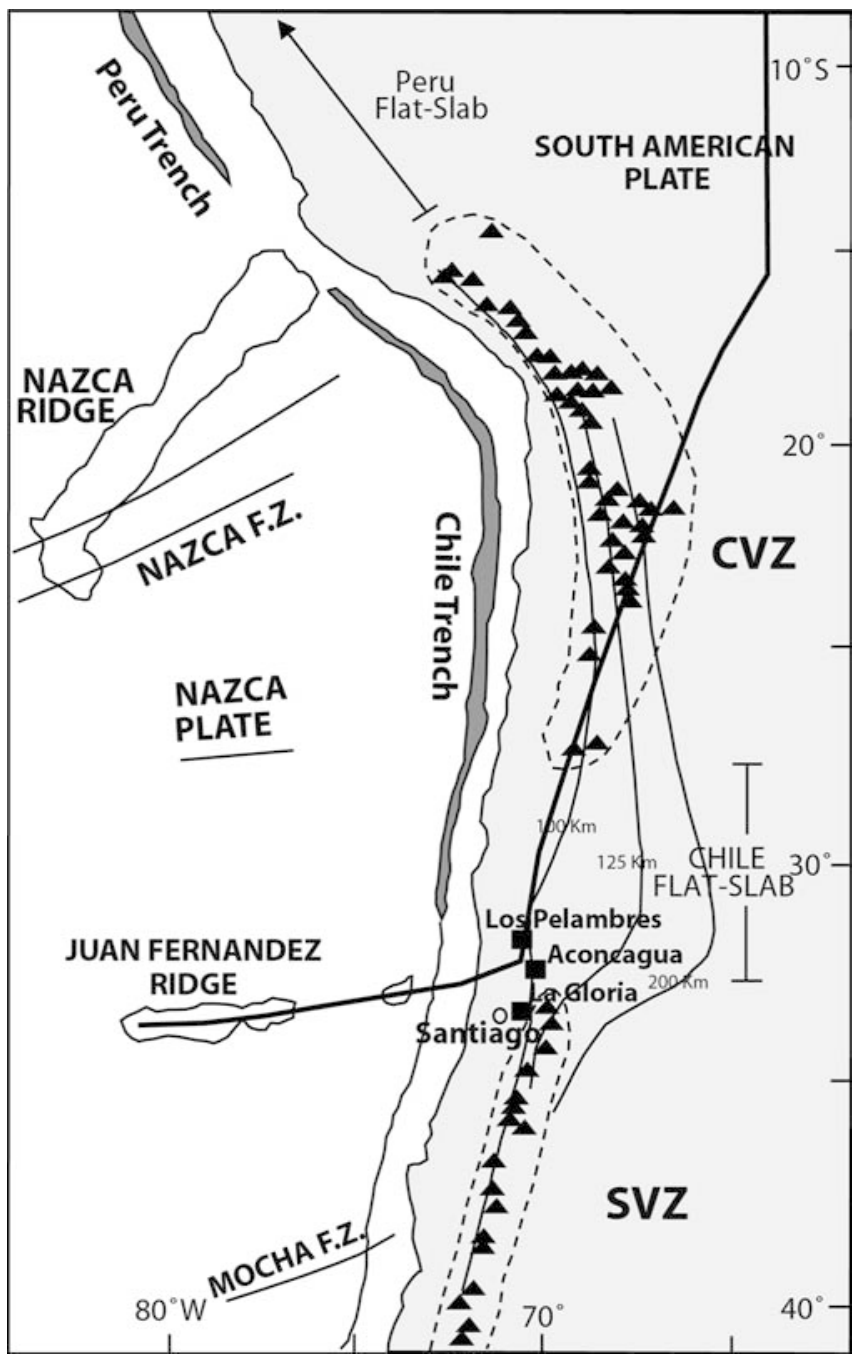

Fig. 1 Map showing the main tectonic features of the southeastern Nazca plate and the Chilean flat-slab segment $\left(28^{-3} 3^{\circ} \mathrm{S}\right)$. The position of the predicted path of the Juan Fernández hotspot chain at $10 \mathrm{Ma}$ (bold black line), and the volcanic gap separating the Central Volcanic Zone $(C V Z)$ and the Southern Volcanic Zone $(S V Z)$ are indicated. The locations of the Los Pelambres porphyry copper deposit, La Gloria pluton and the Aconcagua andesites are also shown. The Wadati-Benioff zone contours were taken from Isacks (1988) comparison with barren magmatic units of similar age (Aconcagua volcanic rocks and La Gloria pluton) and located in the same Late Miocene belt, is presented.

\section{Tectonic setting}

The Los Pelambres deposit is located in the "flat-slab" segment $\left(28-33^{\circ} \mathrm{S}\right)$ of the Chilean Andes, where Recent volcanism is absent (Barazangi and Isacks 1976; Fig. 1). The southernmost end of the flat-slab segment changes gradationally into the "normal-slab" segment of the southern Chilean Andes (33-46 $\left.{ }^{\circ} \mathrm{S}\right)$, characterized by a subduction angle of about $30^{\circ}$, where a continuous belt of modern active volcanoes occurs.

Tectonic and magmatic studies (Kay et al. 1987, 1991; Allmendinger et al. 1990; Reynolds et al. 1990; Kay and Abruzzi 1996; Kay and Mpodozis 2002) concerning the Miocene to Recent evolution of the present-day "flatslab" segment of the Chilean Andes have shown that the subducted oceanic slab shallowed since $\sim 26 \mathrm{Ma}$. During the Early Miocene ( 27-20 Ma) this segment had a subducted slab geometry similar to that currently observed in the normal-slab segment at $35^{\circ} \mathrm{S}$, and a crustal thickness of 35-40 km (Kay et al. 1991; Kay and Abruzzi 1996; Kay and Mpodozis 2002). The shallowing of the subduction zone progressed from Middle to Late Miocene (20-5 Ma), accompanied by crustal thickening, a substantial decrease in the astenospheric wedge thickness, eastward migration and broadening of the arc, and cessation of the magmatic activity over the flat-slab ( $\sim 5 \mathrm{Ma})$. During this period, the crustal thickness along the flatslab segment was different from north to south. The northern $\left(\sim 28-29^{\circ} \mathrm{S}\right)$ and central $\left(\sim 30-31^{\circ} \mathrm{S}\right)$ regions reached a crustal thickness exceeding $55 \mathrm{~km}$ by the end of the Miocene, while the southern region of the flat-slab $\left(31-33^{\circ} \mathrm{S}\right)$ reveals a thinner crust $(\sim 30-35 \mathrm{~km})$ for the same period (Kay et al. 1991). Moreover, the crust below the Middle to Late Miocene magmatic belt south of $33^{\circ} \mathrm{S}$ never thickened to as much as $40 \mathrm{~km}$. South of $33^{\circ} \mathrm{S}$ the magmatic arc migrated eastward during the Pliocene to its current position in the high Andes, where crustal thickness of more than $50 \mathrm{~km}$ occurs (Stern and Skewes 1995).

These changes in the subduction geometry between $28-33^{\circ} \mathrm{S}$ have been related to the collision and subduction of the Juan Fernández Ridge (JFR) hotspot chain (Pilger 1981; Nur and Ben-Avraham 1981, Yáñez et al. 2001, 2002). The cited authors modeled the flat-slab geometry as an effect of the subduction of a buoyant hotspot chain. In this scenario, the contribution of the oceanic lithosphere to the arc magma source would have increased with the decreasing volume of mantle wedge resulting from progressive slab flattening.

\section{Geology of the Los Pelambres porphyry intrusions}

The Los Pelambres porphyry copper mineralization is hosted by an intrusive complex emplaced within a 
sequence of andesitic rocks of the Los Pelambres Formation (Late Cretaceous) (Rivano and Sepúlveda 1991; Atkinson et al. 1996; Fig. 2). The intrusive complex consists of a main tonalite stock and porphyritic bodies, and a small number of post-mineralization andesite and aplite dikes. Magmatic/ hydrothermal breccia pipes also occur within the deposit. Detailed petrographic descriptions and characterization of these bodies were presented by Atkinson et al. (1996).

Tonalites and tonalite porphyries

The tonalites form a stock which hosts the main mineralization. They have a medium grain size $(0.5-3 \mathrm{~mm})$, composed of a subequigranular hypidiomorphic intergrowth of plagioclase (normally zoned, $\mathrm{An}_{30-40}$ ), biotitized hornblende and biotite, with minor quartz and perthitic K-feldspar as interstitial grains. Zircon and apatite are common accessory phases, and sulfides (chalcopyrite, bornite and pyrite) occur as disseminated grains within altered intrusions. Irregular tonalite porphyry bodies are recognized throughout the stock. They have plagioclase phenocrysts, disseminated biotite and biotitized hornblende. The phenocrysts $(\sim 1 \mathrm{~cm})$ are surrounded by a fine-grained quartz/K-feldspar matrix $(0.05-0.15 \mathrm{~mm})$.

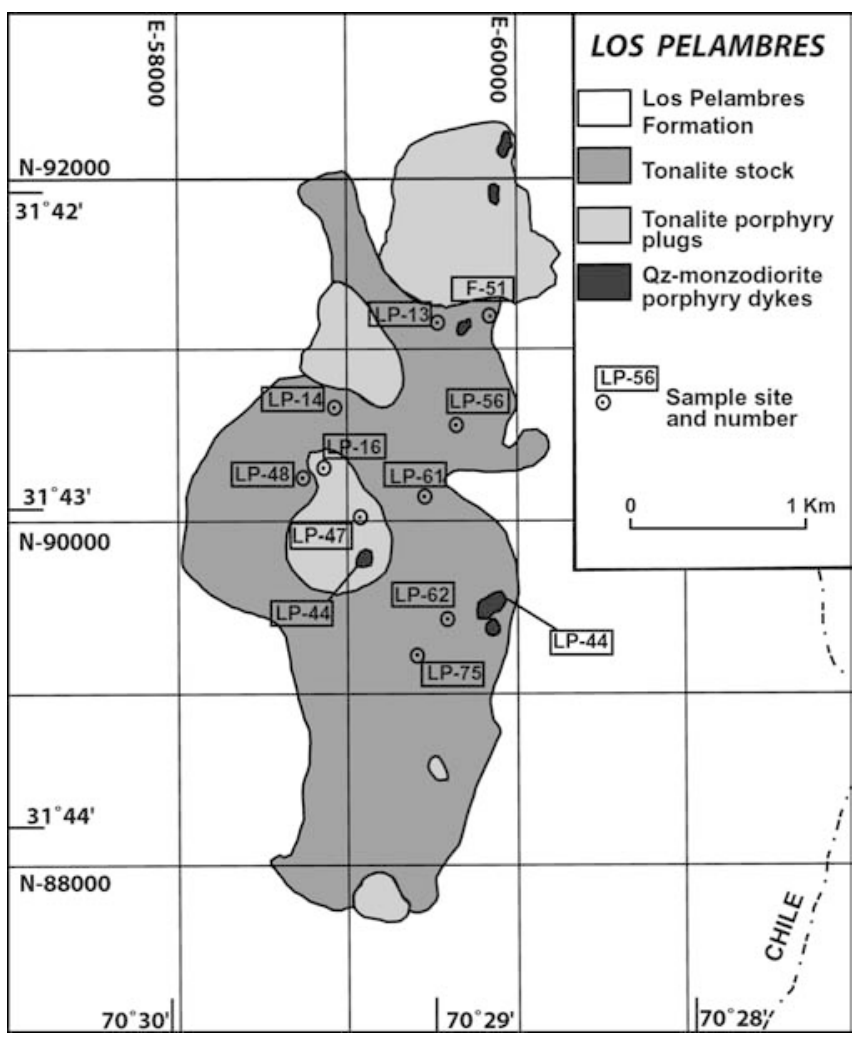

Fig. 2 Geological map of the Los Pelambres porphyry copper deposit, modified from Schultz (1997)
Quartz diorite and quartz monzodiorite porphyries

These porphyries occur as dikes and irregular bodies, and are distributed throughout the central portion of the tonalite stock. Two types of dioritic porphyries are recognized: quartz diorite (Porphyry A) and quartz monzodioritic (Porphyry B) porphyries. Quartz diorite porphyry consists of plagioclase and biotitized hornblende $(2-5 \mathrm{~mm})$ phenocrysts in a biotite trachytic groundmass. Quartz monzodiorite porphyry is composed of plagioclase, biotite and biotitized hornblende immersed in an biotite-bearing aplitic matrix. All these porphyritic rocks are mineralized.

\section{Post-mineralization dikes}

Post-mineralization magmatic events are represented by a late andesite dike (plagioclase phenocrysts in an aphanitic matrix), and aplitic dikes (fine grained quartz and K-feldspar).

\section{Mineralization}

Hypogene and supergene alteration and mineralization at Los Pelambres have been described in detail by Atkinson et al. (1996), who recognized multiple events of ore deposition during the life span of the hydrothermal system. Early hypogene mineralization occurs as disseminated sulfides (chalcopyrite/bornite, traces of molybdenite and pyrite) in alteration halos around veins of a quartz stockwork, associated with potassic alteration. Late mineralization is defined by pyrite veins with sericitic halos. K-Ar dating on hydrothermal biotite (potassic alteration) of the tonalite stock yielded ages of $9.74 \pm 0.16$ and $9.96 \pm 0.18 \mathrm{Ma}$ (Sillitoe 1973). An average K-Ar secondary biotite age of $9.9 \pm 1.0 \mathrm{Ma}$ was obtained from the tonalite and some porphyry facies (Atkinson et al. 1996). Recent Re-Os dating in early and late molybdenite yielded mineralization ages of $10.75 \pm 0.05 \mathrm{Ma}$ and $10.40 \pm 0.05 \mathrm{Ma}$, respectively (Mathur et al. 2001).

\section{Geochemistry of the Los Pelambres intrusions}

Major and trace elements

Major and trace element compositions of selected Los Pelambres intrusive rocks (tonalite, tonalite porphyry, and quartz monzodiorite porphyry) were determined by a combination of XRF, AAS, INAA, ICP-MS and DCP-AES techniques at Bondar Clegg Laboratories, Canada. Representative analyses suitable for petrological work $(\mathrm{LOI}<1.5 \mathrm{wt} \%)$ are given in Table 1 .

The Los Pelambres rocks (tonalite, tonalite porphyry and quartz monzodiorite porphyry) form a suite covering a $\mathrm{SiO}_{2}$ range from $62-72 \mathrm{wt} \%$ (average $\mathrm{SiO}_{2}$ of 
Table 1 Representative major and trace element abundances in Los Pelambres rocks. $T$, Tonalite; $T$ - $P$, tonalite porphyry; $Q D M-P$, quartz-diorite porphyry

\begin{tabular}{|c|c|c|c|c|c|c|c|c|c|c|c|c|}
\hline Sample: & $\begin{array}{l}\mathrm{T} \\
\mathrm{F}-51\end{array}$ & $\begin{array}{l}\text { T } \\
\text { LP-48 }\end{array}$ & $\begin{array}{l}\text { T } \\
\text { LP-75 }\end{array}$ & $\begin{array}{l}\text { T } \\
\text { LP-62 }\end{array}$ & $\begin{array}{l}\mathrm{T} \\
\mathrm{LP}-61\end{array}$ & $\begin{array}{l}\text { T } \\
\text { LP-14 }\end{array}$ & $\begin{array}{l}\text { T } \\
\text { LP-13 }\end{array}$ & $\begin{array}{l}\text { T } \\
\text { LP-56 }\end{array}$ & $\begin{array}{l}\text { T-P } \\
\text { LP-47 }\end{array}$ & $\begin{array}{l}\text { T-P } \\
\text { LP-16 }\end{array}$ & $\begin{array}{l}\text { QMD-P } \\
\text { LP-44 }\end{array}$ & $\begin{array}{l}\text { QMD-P } \\
\text { LP-46 }\end{array}$ \\
\hline $\mathrm{SiO}_{2}$ & 63.7 & 64.2 & 66.0 & 66.3 & 66.8 & 66.9 & 67.0 & 67.6 & 67.2 & 72.2 & 62.7 & 65.1 \\
\hline $\mathrm{TiO}_{2}$ & 0.67 & 0.68 & 0.57 & 0.56 & 0.57 & 0.57 & 0.58 & 0.46 & 0.56 & 0.43 & 0.74 & 0.66 \\
\hline $\mathrm{Al}_{2} \mathrm{O}_{3}$ & 17.7 & 17.8 & 17.2 & 17.1 & 16.8 & 17.2 & 16.9 & 16.5 & 17.5 & 15.2 & 17.8 & 17.0 \\
\hline $\mathrm{Fe}_{2} \mathrm{O}_{3}$ & 4.40 & 3.57 & 3.67 & 3.14 & 2.79 & 2.75 & 2.81 & 3.75 & 1.51 & 0.80 & 4.29 & 3.42 \\
\hline $\mathrm{Na}_{2} \mathrm{O}$ & 5.22 & 5.71 & 5.88 & 4.83 & 5.22 & 5.25 & 4.87 & 5.42 & 8.03 & 6.19 & 5.88 & 5.52 \\
\hline $\mathrm{K}_{2} \mathrm{O}$ & 1.58 & 2.35 & 2.39 & 2.54 & 3.39 & 2.90 & 2.99 & 2.87 & 1.83 & 2.53 & 2.35 & 2.68 \\
\hline $\mathrm{P}_{2} \mathrm{O}_{5}$ & 0.21 & 0.31 & 0.18 & 0.19 & 0.17 & 0.24 & 0.15 & 0.09 & 0.11 & 0.11 & 0.26 & 0.25 \\
\hline $\mathrm{LOI}^{\mathrm{a}}$ & 1.17 & 1.30 & 1.44 & 1.16 & 0.91 & 1.05 & 1.46 & 1.15 & 1.22 & 0.95 & 1.47 & 1.25 \\
\hline Total & 99.6 & 100.3 & 101.5 & 99.6 & 100.0 & 100.3 & 99.7 & 100.7 & 100.3 & 100.1 & 99.9 & 100.1 \\
\hline $\mathrm{Mg}^{\mathrm{b}}$ & 41.9 & 52.2 & 46.4 & 50.1 & 52 & 51.8 & 48.4 & 37.8 & 70.7 & 75.9 & 55.9 & 56.5 \\
\hline $\mathrm{Cr}$ & nd & 9 & 10 & 7 & 1 & 4 & 5 & nd & 17 & 3 & 46 & 12 \\
\hline $\mathrm{Ni}$ & 4 & 6 & 7 & 5 & 4 & 3 & 7 & 5 & 11 & 2 & 13 & 13 \\
\hline $\mathrm{Nb}$ & 4 & 5 & 7 & 1 & 10 & 3 & 4 & 6 & 1 & 5 & 5 & 4 \\
\hline $\mathrm{Zr}$ & 131 & 127 & 130 & 121 & 128 & 124 & 128 & 111 & 117 & 103 & 116 & 115 \\
\hline $\mathrm{Hf}$ & 4.45 & 3.68 & 5.00 & 4.07 & 3.94 & 4.21 & 4.21 & 3.56 & 3.53 & 3.45 & 3.49 & 3.48 \\
\hline Ta & 0.5 & 0.9 & - & - & - & 1.0 & 1.0 & - & $<0.5$ & - & 0.7 & $<0.5$ \\
\hline $\mathrm{La}$ & 19.5 & 18.4 & 16.6 & 16.2 & 14.5 & 24.0 & 17.3 & 14.0 & 17.6 & 16.2 & 15.2 & 19.5 \\
\hline $\mathrm{Ce}$ & 38.1 & 37.3 & 35.2 & 36.2 & 30.5 & 49.9 & 35.3 & 28.3 & 35.7 & 31.3 & 30.7 & 30.7 \\
\hline $\operatorname{Pr}$ & 4.61 & 4.58 & 4.27 & 4.24 & 3.44 & 6.29 & 3.97 & 3.04 & 4.28 & 3.64 & 3.81 & 3.81 \\
\hline $\mathrm{Nd}$ & 17.0 & 16.8 & 15.4 & 15.3 & 11.9 & 22.4 & 13.5 & 10.9 & 15.3 & 12.5 & 14.1 & 14.1 \\
\hline $\mathrm{Sm}$ & 2.95 & 2.73 & 2.62 & 2.79 & 1.90 & 3.88 & 2.13 & 1.82 & 2.40 & 1.90 & 2.48 & 2.48 \\
\hline $\mathrm{Eu}$ & 0.96 & 0.849 & 0.742 & 0.802 & 0.566 & 0.972 & 0.633 & 0.541 & 0.539 & 0.444 & 0.691 & 0.691 \\
\hline Gd & 2.16 & 1.87 & 1.66 & 1.98 & 1.22 & 2.43 & 1.38 & 1.1 & 1.3 & 1.08 & 1.76 & 1.76 \\
\hline
\end{tabular}

${ }^{\text {a }}$ Loss On Ignition at $950{ }^{\circ} \mathrm{C}$

${ }^{\mathrm{b}} 100 * \mathrm{MgO} /\left[\mathrm{MgO}+\mathrm{Fe}_{2} \mathrm{O}_{3}\right]$

$63.3 \mathrm{wt} \%$ ), and are characterized by high $\mathrm{Al}_{2} \mathrm{O}_{3}$ (15.2$17.8 \mathrm{wt} \%)$ and $\mathrm{Na}_{2} \mathrm{O}(4.8-6.6 \mathrm{wt} \%)$ abundances, with $\mathrm{K}_{2} \mathrm{O} / \mathrm{Na}_{2} \mathrm{O}<1 \quad(0.23-0.71)$ and an $\mathrm{Al}_{2} \mathrm{O}_{3} /(\mathrm{CaO}+$ $\mathrm{Na}_{2} \mathrm{O}+\mathrm{K}_{2} \mathrm{O}$ ) molar ratio of about 1.0. They have low $\mathrm{MgO}$ between 1.2-2.7 wt \%, and the magnesian numbers ( $\# \mathrm{Mg}=100 * \mathrm{MgO} /\left[\mathrm{MgO}+\mathrm{Fe}_{2} \mathrm{O}_{3}\right]$, molar) are moderately high, ranging from 38 up to 75 . Major element variation diagrams show a negative correlation for $\mathrm{Al}_{2} \mathrm{O}_{3}, \mathrm{CaO}, \mathrm{Fe}_{2} \mathrm{O}_{3}, \mathrm{MgO}, \mathrm{TiO}_{2}$ and $\mathrm{P}_{2} \mathrm{O}_{5}$, while $\mathrm{Na}_{2} \mathrm{O}$ and $\mathrm{K}_{2} \mathrm{O}$ indicate incompatible behavior for the whole silica range (Fig. 3).

Trace element abundances of the Los Pelambres rocks show high $\mathrm{Sr}(306-750 \mathrm{ppm})$ and low $\mathrm{Y}$ (1.59-6.55 ppm), with high $\mathrm{Sr} / \mathrm{Y}$ ratios $(\sim 100-300)$ (Fig. 4a). $\mathrm{Cr}$ (1-17 ppm), $\mathrm{Ni}(2-12 \mathrm{ppm})$ and $\mathrm{Nb}$ (1-10 ppm) contents are low (except for quartz monzodiorite porphyry sample LP-44, where $\mathrm{Cr}=46 \mathrm{ppm}$ ). Chondrite-normalized rare earth element (REE) patterns of the Los Pelambres rocks are strongly fractionated, with light rare earth element (LREE) enrichment and heavy REE (HREE) depletion (low Yb: 0.143-0.592 ppm; high $\mathrm{La}_{\mathrm{N}} / \mathrm{Yb}_{\mathrm{N}}$ : 25-60; Fig. 4). REE patterns display a steep negative slope with an inflection at $\mathrm{Tb}$, and no $\mathrm{Eu}$ anomalies $\left(\mathrm{Eu} / \mathrm{Eu}^{*} \sim 1\right)$ are observed (Fig. 5).

\section{$\mathrm{Sr}-\mathrm{Nd}$ isotopic compositions}

$\mathrm{Sr}$ and $\mathrm{Nd}$ isotopic compositions were determined for three samples of the Los Pelambres tonalite stock (F-51, LP-48, LP-75; Table 2). The Sr-Nd analytical determinations were performed at the Centro de Instrumentación Científica, Universidad de Granada, Spain, using a Finnegan MAT 262 thermal ionization mass spectrometer (TIMS) with variable multicollector and RPQ. ${ }^{87} \mathrm{Sr} /{ }^{86} \mathrm{Sr}$ was normalized using ${ }^{88} \mathrm{Sr} /{ }^{86} \mathrm{Sr}=8.375209$, with a $0.0007 \%(2 \sigma)$ reproducibility under successive 
Fig. 3 Major elements variation diagram of samples from the Los Pelambres intrusions. The compositional fields of the coeval La Gloria pluton and Aconcagua volcanic rocks according to data in Cornejo (1990) and Kay et al. (1991)
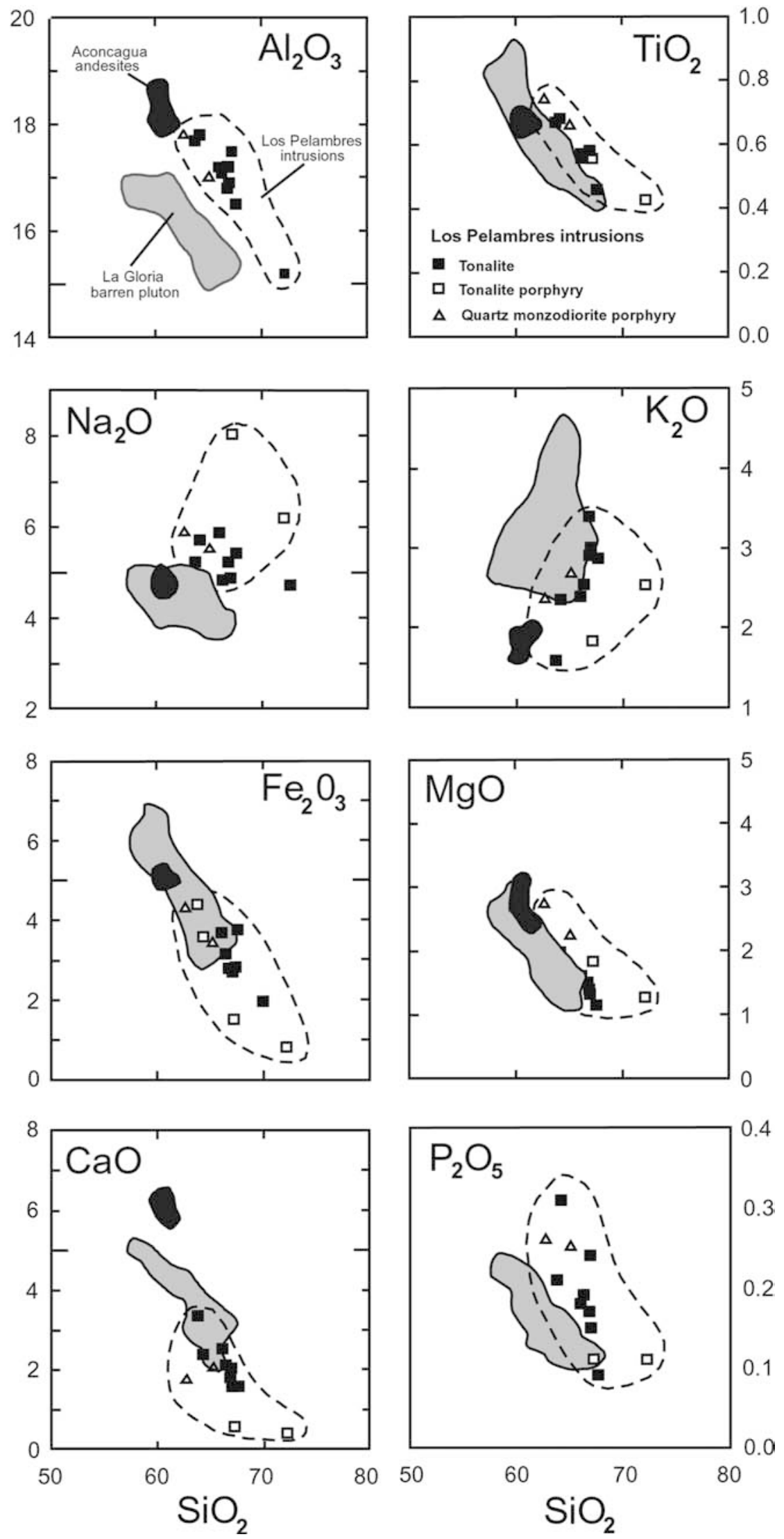
Fig. $4 \mathrm{Sr} / \mathrm{Y}$ versus $\mathrm{Y}$, and $\mathrm{La}_{\mathrm{N}} /$ $Y b_{N}$ versus $Y b_{N}$ discrimination diagrams for the Los Pelambres intrusions, La Gloria pluton and Aconcagua volcanic rocks. The adakitic and ADR (Andesite-Dacite-Rhyolite) fields were taken from Martin (1999)

Fig. 5 Chondrite-normalized REE diagram of Los Pelambres rocks. Fields of La Gloria and Aconcagua samples are also shown. Normalizing factors after Nakamura (1974)
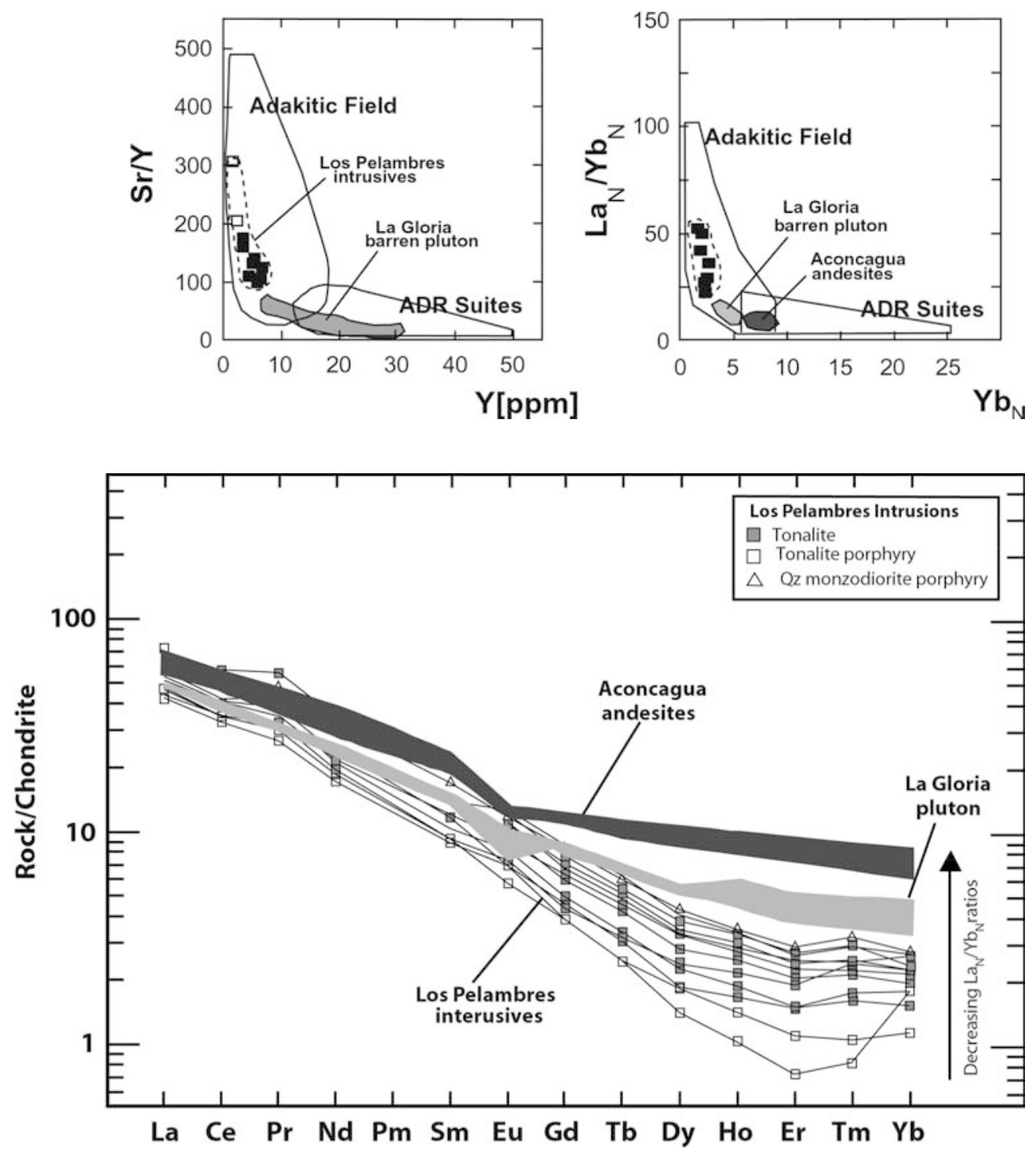

determinations of the NBS-987 dissolved standard. The ${ }^{143} \mathrm{Nd} /{ }^{144} \mathrm{Nd}$ ratios, normalized using ${ }^{146} \mathrm{Nd} /{ }^{144} \mathrm{Nd}=$ 0.7219 showed precision better than $0.0016 \%(2 \sigma)$ calculated from successive measurements of the WSE powder standard. Initial ratios were calculated assuming a Late Miocene age of $10 \mathrm{Ma}$. The $\mathrm{Sr}$ and $\mathrm{Nd}$ isotopic isotopic compositions of the Late Miocene Los Pelambres intrusives reveal initial ${ }^{87} \mathrm{Sr} /{ }^{86} \mathrm{Sr}$ ratios between 0.70439 and 0.70465 , while ${ }^{143} \mathrm{Nd} /{ }^{144} \mathrm{Nd}$ ratios range from 0.512619 to 0.512635 . In terms of $\epsilon_{\mathrm{Nd}}$, the Los Pelambres rocks exhibit values close to zero.

Comparison with contemporaneous barren igneous rocks

The geochemical composition of the Los Pelambres rocks is contrasted with the contemporaneous Late Miocene La Gloria pluton (9.8 Ma, cf. Cornejo 1990) and the Cerro Aconcagua andesites (10.3-9 Ma; cf. Kay and Mpodozis 2002), selected as representative magmatic units located in the southern portion of the current flat-slab Andean segment. The La Gloria pluton is an equigranular granodiorite to quartz-monzodiorite epizonal barren intrusion, extending over $100 \mathrm{~km}^{2}$, that is located $40 \mathrm{~km}$ east of Santiago City (ca. $33^{\circ} 30^{\prime} \mathrm{S}$; Cornejo and Mahood 1997). The Late Miocene Cerro Aconcagua magmatic center is located on the ChileArgentina border $\left(32^{\circ} 40^{\prime} \mathrm{S}, 70^{\circ} \mathrm{W}\right), 120 \mathrm{~km}$ northeast of Santiago. Chemical data from the La Gloria pluton are mostly taken from Cornejo (1990). Additional chemical and $\mathrm{Sr}-\mathrm{Nd}$ isotopic compositions were obtained for sample G-318 of this pluton (Table 2). Chemical and isotopic data from the Cerro Aconcagua andesitic lava flows and breccias (upper level) were taken from Kay et al. (1991).

When compared with the barren La Gloria and Aconcagua magmatic rocks, fresh samples from the Los Pelambres rocks display distinct chemical differences, mainly noticeable in their trace element signature. They are $\mathrm{Al}_{2} \mathrm{O}_{3}$ and $\mathrm{Na}_{2} \mathrm{O}$-enriched, together with higher $\mathrm{Sr} / \mathrm{Y}$ and $\mathrm{La}_{\mathrm{N}} / \mathrm{Yb}_{\mathrm{N}}$ ratios, and the strongly fractionated, 
Table $2 \mathrm{Sr}-\mathrm{Nd}$ isotope data for the Los Pelambres porphyries, La Gloria pluton and Cerro Aconcagua andesites

\begin{tabular}{|c|c|c|c|c|c|c|c|c|c|}
\hline Sample & Unit & Lithology & Age (Ma) & ${ }^{87} \mathrm{Sr} /{ }^{86} \mathrm{Sr}$ & Error $(2 \sigma \%)$ & ${ }^{143} \mathrm{Nd} /{ }^{144} \mathrm{Nd}$ & Error $(2 \sigma \%)$ & $\left({ }^{87} \mathrm{Sr} /{ }^{86} \mathrm{Sr}\right)_{\mathrm{i}}$ & $\epsilon_{\mathrm{Nd}}{ }^{\mathrm{t}}(\mathrm{CHUR})$ \\
\hline LP-48 & Pelambres & Tonalite & $9.9 \pm 1.0$ & 0.70471 & 0.002 & 0.512635 & 0.0016 & 0.70465 & 0.06 \\
\hline G-318 & La Gloria & Granodiorite & $9.8^{\mathrm{b}}$ & 0.70408 & 0.003 & 0.512771 & 0.0020 & 0.70401 & 2.70 \\
\hline $\mathrm{ACON} 103^{\mathrm{c}}$ & Aconcagua & Andesite & 8.9 & 0.704548 & 0.0007 & 0.512597 & 0.0008 & 0.70446 & -0.3 \\
\hline
\end{tabular}

${ }^{\mathrm{a}}$ Atkinson et al. (1996)

${ }^{\mathrm{b}}$ Cornejo (1990)

${ }^{\mathrm{c}}$ Data in Kay et al. (1991)

HREE-depleted chondrite-normalized patterns contrast with the rather flat, less fractionated REE patterns from La Gloria and Aconcagua (Figs. 3, 4, 5). The Los Pelambres rocks have $\mathrm{Sr}$ initial ratios similar to those reported for the La Gloria pluton and the Aconcagua andesites (Table 2). On the other hand, the $\epsilon_{\mathrm{Nd}}$ values of the Los Pelambres rocks are similar to that of the Aconcagua andesites, but lower than that obtained on the La Gloria pluton.

\section{The adakite-like signature of the Los Pelambres rocks: an oddity in the Late Miocene magmatism of central Chile}

\section{Adakitic affinity}

The term adakite was introduced by Kay (1978) and has been used to describe high-Al and Na-rich andesitic to dacitic, extrusive or intrusive rocks with a high $\mathrm{Sr}$ content $(>600 \mathrm{ppm})$, strongly fractionated REE patterns (HREE depleted, LREE enriched), among other features, which were interpreted as resulting from slab melting where garnet and hornblende are residual phases. With the exception of the low $\mathrm{MgO}$ contents, the Los Pelambres rocks display an adakitic major and trace element geochemical affinity, following the criteria defined by Defant and Drummond (1990), Drummond and Defant (1990), Drummond et al. (1996) and Martin (1999). One of the most relevant chemical features of this particular type of magmatism can be seen in the $(\mathrm{Sr} /$ $\mathrm{Y})$ vs. $\mathrm{Y}$ and $\left(\mathrm{La}_{\mathrm{N}} / \mathrm{Yb}_{\mathrm{N}}\right)$ vs $\mathrm{Yb}_{\mathrm{N}}$ discrimination diagrams (Fig. 4), where the Los Pelambres intrusive rocks plot well within the adakitic field. The Na-rich rocks of Los Pelambres show the typical trondhjemitic character recognized in adakitic rock suites, when plotted on an Ab-An-Or normative diagram (Barker 1979) (Fig. 6). Similary, the low $\mathrm{Nb} / \mathrm{Ta}(3.0-8.0)$ and high $\mathrm{Zr} / \mathrm{Sm}$ (3260) ratios are comparable with those recorded in TTG gneisses and modern adakites (Foley et al. 2002). On the other hand, the $\mathrm{Sr}-\mathrm{Nd}$ isotopic composition of the Los Pelambres porphyries is more radiogenic than most typical adakites, whose $\mathrm{Sr}-\mathrm{Nd}$ values are close to MORB $\left({ }^{144} \mathrm{Nd} /{ }^{143} \mathrm{Nd}>0.5129\right.$ and ${ }^{87} \mathrm{Sr} /{ }^{86} \mathrm{Sr}<0.705$; Martin 1999). These isotopic differences to true adakites are attributable to participation of crustal components in flat-slab subduction magmatism (see below).
Under subduction settings constrained by particular $\mathrm{P}-\mathrm{T}-\mathrm{H}_{2} \mathrm{O}$ conditions $\left(\mathrm{P} \geq 5 \mathrm{kbar}, \mathrm{T} \geq 750{ }^{\circ} \mathrm{C},>10 \mathrm{wt} \%\right.$ $\mathrm{H}_{2} \mathrm{O}$ ), young $(\leq 25 \mathrm{Ma})$, mafic oceanic lithosphere melts before reaching dehydration, generating adakitic magmas with a MORB-like isotopic signature, instead of typical calc-alkaline arc andesite-dacite-rhyolite suites, originating by partial melting of a metasomatized mantle wedge (Drummond et al. 1996; Martin 1999; Prouteau et al. 1999). However, adakite-type melts may also result from partial melting of overthickened mafic lower crust equilibrated with a garnet-hornblende residual mineralogy (e.g., Kay et al. 1987, 1991; Petford and Atherton 1996; Kay and Mpodozis 2001).

The source of the Los Pelambres intrusions

The identification of the magma source of porphyry copper systems has been the subject of long-standing controversy. Particulary interesting is the debate generated after Oyarzún et al.'s (2001) model for the formation of the adakite-like Late Eocene-Early Oligocene

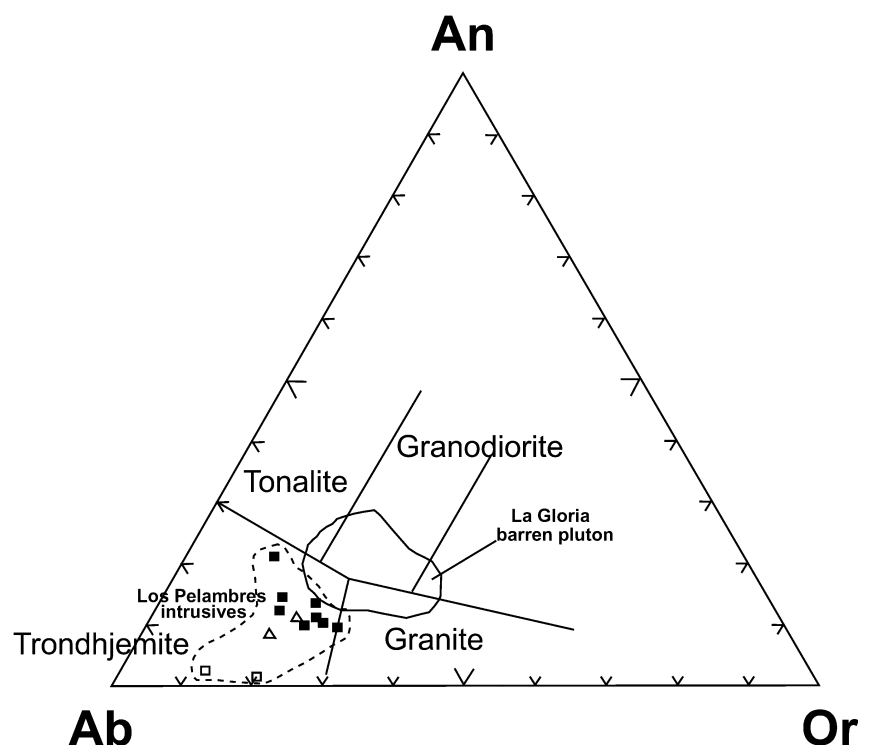

Fig. $6 \mathrm{Ab}-\mathrm{An}-\mathrm{Or}$ normative diagram (Baker 1979) showing the fields of Los Pelambres and La Gloria rocks. Los Pelambres samples show the typical trodhjemitic character recognized in adakitic rocks 
porphyry copper systems of northern Chile by melting of the oceanic slab (Richards 2002; Rabbia et al. 2002). Because the adakitic signatures are not exclusively derived by slab melting and have also been explained by crustal participation either as a source contaminant or as a protholith after crustal thickening (e.g., Petford and Atherton 1996; Kay and Mpodozis 2002), a combination of geochemical and geodynamic evidence is needed to better understand its origin. In the following discussion we present such evidence to constrain the source of the Los Pelambres rocks.

With the exception of adakites recognized along the Austral Volcanic Zone (49-54 ${ }^{\circ}$; ; Stern et al. 1984; Futa and Stern 1988; Kay et al. 1993; Stern and Kilian 1996), where young, hot and buoyant oceanic lithosphere $(<24 \mathrm{Ma})$ is subducted under a relatively thin crust $(<35 \mathrm{~km})$, no modern adakites have been documented in the Chilean Andes. A recent thermal model given by Gutscher et al. (2000) has shown that slab melting before dehydration is viable under flat-slab conditions similar to those recognized further north along the Andes. The authors tested the model in the central Andes flat-slab segment to explain adakite-type rocks erupted between 10 and $4 \mathrm{Ma}$, but this was questioned by Kay and Mpodozis (2002), based on geological and geochemical arguments. They argued that the Eocene age of the Nazca plate that is subducting beneath the central Chile Andes (Yáñez et al. 2001) is too old to favor slab melting, and indicated that these rocks are better explained by contamination of arc-derived magmas by deep garnet granulite and eclogite rocks of a thickened crust or by crust tectonically incorporated (subduction erosion) into the mantle source. The explanation based on a thickened crust is unlikely for the case of the studied adakite-like rocks because the crustal thickness for the Los Pelambres region may not have reached more than $35 \mathrm{~km}$ at the time of the ore deposit formation (cf. Kay et al. 1991). In addition, melting of an overthickened mafic lower crust implies major crustal processes, which might have a regional expression. On the contrary, the adakite-like signature of Los Pelambres rocks is an oddity along the Late Miocene belt of Central Chile. For example, the contemporaneous La Ramada (c. $32^{\circ} \mathrm{S}$; see Kay and Mpodozis 2002 for geochemical characteristics) and Aconcagua volcanic centers, and the La Gloria pluton have a typical arc geochemical composition with moderate $\mathrm{La} / \mathrm{Yb}$ ratios and differ largely from the adakitic signature of the Los Pelambres intrusions.

The Late Miocene adakite-like rocks from Los Pelambres are closely related in time and space with changing subduction conditions. In fact, tectonic reconstructions by Yáñez et al. $(2001,2002)$ revealed that the JFR hotspot chain migrated from north to south along the Chilean margin since the Early Miocene to its actual position in central Chile. These reconstructions show that the oblique interaction between a NE segment of the ridge and the trench migrated rapidly southward along the Chilean margin since the Early Miocene in northern Chile $\left(19^{\circ} \mathrm{S}\right)$ to the Late Miocene $(\sim 10 \mathrm{Ma})$ at the latitude of Los Pelambres, where a W-E segment of the JFR hotspot track started to subduct (Fig. 1). This caused a dramatic slowdown of the southward migration of the ridge-trench interaction and coincided with the termination of the frontal arc andesitic volcanism (Kay and Mpodozis 2002). In this scenario we favor an alternative explanation based on the particular case of partial melting of rocks of the W-E segment of the JFR hotspot chain, when it started to migrate slowly southward, allowing to build up a sufficient volume of magma to ascend. These locally restricted tectonic conditions may explain why adakite-like rocks were not found in contemporaneous igneous rocks formed in the same belt. During the formation of the Los Pelambres deposit, the age of the subjacent hotspot rocks was about $10 \mathrm{Ma}$ older (Yáñez et al. 2001), thus it is likely that the hotspot source rocks were at a sufficient temperature to reach partial melting before dehydration was completed. The latter assumption is based on the low $\mathrm{Nb} / \mathrm{Ta}$ and high $\mathrm{Zr} / \mathrm{Sm}$ ratios, which are considered to result from melting of an amphibolite or garnet-amphibolite source (Foley et al. 2002). The isotopic differences observed between the Los Pelambres rocks and the typical depleted adakites can be explained by the incorporation of more radiogenic crustal material tectonically dragged by the subducting ridge to the Los Pelambres magma source depth (Kay and Mpodozis 2002) and/or the inheritance of a more radiogenic OIB signature of the source. It is noteworthy that the tectonic erosion mechanism would have been operative in Central Chile since $15 \mathrm{Ma}$ (Stern 1991). The decreasing thickness of the mantle wedge by combination of both slab shallowing and incorporation of tectonically eroded crustal material to the source region, could explain the lower $\mathrm{MgO}$ contents of the Los Pelambres rocks compared to true adakites. In fact, the high $\mathrm{MgO}$ contents of adakites have been interpreted as due to slab melt-mantle wedge interaction (Kay 1978; Kay et al. 1993; Sen and Dunn 1994).

\section{Is the subducting lithosphere the source of metals?}

There has been growing interest in adakitic magmatism and its relation to copper and gold mineralization during the last decade. An association between adakites and ore deposits has been documented, for example, at Mount Pinatubo in Luzon, Philippines, where small Pliocene to Quaternary porphyry copper-gold deposits occur in the vicinity of the summit of the volcano (Sillitoe and Gappe 1984; Malihan 1987; Imai et al. 1993). In addition, adakites in east Mindanao, Philippines, are associated with Plio-Pleistocene copper and gold porphyry/epithermal systems (Maury et al. 1996; Sajona and Maury 1998). Pasteris (1996) proposed that "open to sulfur" systems (e.g., with huge amounts of sulfur released to the 
atmosphere), such as the adakitic Mount Pinatubo volcano, represent aborted or failed porphyry copper deposits.

In the Chilean Andes, which host the largest concentration of world-class copper deposits on Earth, adakite-like rocks have been recognized associated with Oligocene porphyry copper deposits, suggesting a metallogenic connection between this particular magmatism and porphyry copper formation (Thiéblemont et al. 1997). Furthermore, a controversial causal relationship between adakitic magmatism and the size of porphyry copper deposits in northern Chile has been suggested by Oyarzún et al. (2001). They proposed that Late EoceneEarly Oligocene giant porphyry copper deposits such as Chuquicamata, are related to adakitic, highly oxidized, water-rich melts, and suggested that these melts were eventually derived from a slab source under flat subduction conditions, evolving as closed systems at depth. The genetic link between oceanic lithosphere and the origin of the Los Pelambres deposit seems to be clearer than that given by Oyarzún et al. (2001) for the Chilean Late Eocene-Early Oligocene porphyry copper deposits, because the geodynamic setting is better constrained. In the case studied here, we recognized a close temporal and spatial relationship between a particular ocean floor structure and the formation of the Los Pelambres rocks. In fact, the robust paleotectonic reconstructions of the floor of the Pacific Ocean and geochemical evidence of the Los Pelambres igneous rocks, suggest that its magma source could be related to the JFR subduction and equilibrated under garnet-amphibolite facies. The fluid release on breakdown of an amphibole-bearing residual mineralogy to garnet-bearing assemblages during the melting process has been considered of fundamental importance for the formation of the large central Andean ore deposits (Kay et al. 1999; Kay and Mpodozis 2001). In this scenario, recycling of metals associated with both the magmatic activity of a subducted hotspot chain and crustal material tectonically incorporated into the source region could be a relevant process to explain the origin of the mineralization in the Los Pelambres porphyry copper deposit. However, this mechanism does not explain why contemporaneous rocks such as the nearby La Gloria intrusion apparently lack mineralization.

Although the Los Bronces-Rio Blanco and El Teniente porphyry copper systems located southward (33 and $34^{\circ} \mathrm{S}$, respectively) have steep REE patterns and high $\mathrm{Sr}$ contents (Kay et al. 1999; Rabbia et al. 2000), the proposed genesis of the Los Pelambres rocks cannot be extended to them. These deposits are younger (Early Pliocene; cf. Serrano et al. 1996; Stern and Skewes 1995) and emplaced beyond the influence area of the JFR as a source region. In the case of the Los Bronces-Rio Blanco deposit, the high $\mathrm{La} / \mathrm{Yb}$ ratios that are exhibited by small volumes of late intrusive rocks, correlate with higher $\mathrm{SiO}_{2}$ values, which has been interpreted as due to late stage fractional crystallization involving amphibole (López-Escobar 1982).
Acknowledgments Comments by S. Kay and an anonymous reviewer helped to improve the final manuscript. This study was financed by Volkswagen-Stiftung (I-71649). We appreciate the facilities provided by Compañía Minera Los Pelambres.

\section{References}

Atkinson WW Jr, Souviron A, Vehrs TI, Faunes GA (1996) Geology and mineral zoning of the Los Pelambres porphyry copper deposit, Chile. In: Camus F, Sillitoe RH, Petersen R (eds) Andean copper deposits: new discoveries, mineralization, styles and metallogeny. Soc Econ Geol Spec Publ 5:131156

Allmendinger RW, Figueroa D, Snyder D, Beer L, Mpodozis C, Isacks BL (1990) Foreland shortening and crustal balancing in the Andes at $30^{\circ} \mathrm{S}$ latitude. Tectonics 9:789-809

Barazangi M, Isacks BL (1976) Spatial distribution of earthquakes and subduction of the Nazca plate beneath South America. Geology 4:686-692

Barker F (1979) Trondhjemites: definition, environment and hypothesis of origin. In: Barker F (ed) Trondhjemites, dacites and related Rocks. Elsevier, Amsterdam, pp 1-12

Cahill T, Isacks BL (1992) Seismicity and shape of the subducted Nazca plate. J Geophys Res 97:17503-17529

Cathles LM (1981) Fluid flow and genesis of hydrothermal ore deposits. In: Skinner BJ (ed) Economic geology. 75th anniversary volume, pp 424-457

Cornejo P (1990) Geology, mineral compositions, and magmatic gradients of a zoned pluton: La Gloria pluton, central Chilean Andes. MSc Thesis, Stanford University, $160 \mathrm{pp}$

Cornejo P, Mahood GA (1997) Seeing past the effects of re-equilibration to reconstruct magmatic gradients in plutons: La Gloria pluton, central Chilean Andes. Contrib Mineral Petrol 127:159-175

Defant MJ, Drummond MS (1990) Derivation of some modern magmas by melting of young subducted lithosphere. Nature 347:662-665

Drummond MS, Defant MJ (1990) A model for trondhjemitetonalite-dacite genesis and crustal growth via slab melting. J Geophys Res 95:21503-21521

Drummond MS, Defant MJ, Kepezhinkas PK (1996) The petrogenesis of slab derived trondhjemite-tonalite-dacite/adakite magmas. Transact R Soc Edinb Earth Sc 87:205-216

Foley S, Tiepolo M, Vannucci R (2002) Growth of early continental crust controlled by melting of amphibolite in subduction zones. Nature 417:837-840

Futa K, Stern CR (1988) Sr and Nd isotopic and trace element compositions of quaternary volcanic centers of the southern Andes. Earth Planet Sci Lett 88:253-262

Gutscher MA, Maury R, Eissen JP, Bourdon E (2000) Can slab melting be caused by flat subduction? Geology 28:535-538

Hedenquist JW, Lowenstern JB (1994) The role of magmas in the formation of hydrothermal ore deposits. Nature 370:519-526

Imai A, Listanco EL, Fujii T (1993) Petrologic and sulfur isotopic significance of highly oxidized and sulfur-rich magma of Mt. Pinatubo, Philippines. Geology 22:699-702

Isacks BL (1988) Uplift of the central Andean plateau and bending of the Bolivian orocline. J Geophys Res 93:3211-3231

Kay RW (1978) Aleutian magnesian andesites: Melts from subducted Pacific ocean crust. J Volcanol Geotherm Res 4:117-132

Kay SM, Maksaev V, Mpodozis C, Moscoso R, Nasi C (1987) Probing the evolving Andean lithosphere: Mid-Late Tertiary magmatism in Chile $\left(29-30.5^{\circ} \mathrm{S}\right)$ over the zone of subhorizontal subduction. J Geophys Res 92:6183-6189

Kay SM, Mpodozis C, Ramos VA, Munizaga F (1991) Magma source variations for mid-late Tertiary magmatic rocks associated with a shallowing subduction zone and a thickening crust in the central Andes $\left(28-33^{\circ} \mathrm{S}\right)$. In: Harmon RS, Rapela CW (eds) Andean magmatism and its tectonic setting. Geol Soc Am Spec Pap 265, pp 113-137 
Kay SM, Ramos VA, Márquez M (1993) Evidence in Cerro Pampa volcanic rocks for slab-melting prior to ridge-trench collision in southern South America. J Geol 101:703-714

Kay SM, Abruzzi JM (1996) Magmatic evidence for Neogene lithospheric evolution of the central Andean "flat-slab" between $30^{\circ} \mathrm{S}$ and $32^{\circ} \mathrm{S}$. Tectonophysics $259: 15-25$

Kay SM, Mpodozis C, Coira B (1999) Neogene magmatism, tectonism and mineral deposits of the central Andes $\left(22^{\circ}\right.$ to $33^{\circ} \mathrm{S}$ Latitude). In: Skinner BJ (ed) Geology and ore deposits of the central Andes. Soc Econ Geol Spec Publ 7: pp 27-59

Kay SM, Mpodozis C (2001) Central Andes ore deposits linked to evolving shallow subduction systems and thickening crust. GSA Today 11:4-9

Kay SM, Mpodozis C (2002) Magmatism as a probe to the Neogene shallowing of the Nazca of the Nazca plate beneath the modern Chilean flat-slab. J S Am Earth Sci 15:39-57

López-Escobar L (1982) Características geoquímicas de rocas ígneas asociadas con pórfidos cupríferos chilenos. Rev Geol Chile 17:3-19

Malihan TD (1987) The gold-rich Dizon porphyry copper mine in the western central Luzon Island, Philippines: Its geology and tectonic setting. Proceedings of the Pacific Rim Congress '87, Australian Institute of Mining and Metallurgy, Parkville, Victoria, Australia, pp 303-307

Martin H (1999) Adakitic magmas: modern analogues of Archean granitoids. Lithos 46:411-429

Mathur R, Ruiz JR, Munizaga FM (2001) Insights into Andean metallogenesis from the perspective of Re-Os analyses of sulfides. In: South American symposium on isotope geology, extended abstracts volume (CD version), Soc Geol Chile, Santiago, Chile

Maury RC, Sajona FG, Pubellier M, Bellon H, Defant MJ (1996) Fusion de la croûte océanique dans les zones de subduction/ collision récentes: l'exemple de Mindanao (Philippines). Bull Soc Géol Fr 167:579-595

Nakamura N (1974) Determination of REE, Ba, Fe, Mg, Na and K in carbonaceous and ordinary chondrites. Geochim Cosmochim Acta 38:757-773

Nur A, Ben-Avraham Z (1981) Volcanic gaps and the consumption of aseismic ridges in South America. Geol Soc Am Mem 154:729-740

Oyarzún R, Márquez A, Lillo J, López I, Rivera S (2001) Giant versus small porphyry copper deposits of Cenozoic age in northern Chile: adakitic versus normal calc-alkaline magmatism. Miner Deposita 36:794-798

Pasteris JD (1996) Mount Pinatubo volcano and "negative" porphyry copper deposits. Geology 24:1075-1078

Petford N, Atherton M (1996) Na-rich partial melts from newly underplated basaltic crust: the Cordillera Blanca batholith, Peru. J Petrol 37:1491-1521

Pilger RH (1981) Plate reconstructions, aseismic ridges, and low angle subduction beneath the Andes. Geol Soc Am Bull 92: $448-456$

Prouteau G, Scaillet B, Pichavant M, Maury RC (1999) Fluidpresent melting of oceanic crust in subduction zones. Geology 27:1111-1114

Rabbia OM, Reich M, Hernández LB, King RW, López-Escobar L (2000) High-Al TTG-like suite at the El Teniente porphyry copper deposit, Chile. $9^{\text {th }}$ Congreso Geológico Chileno Puerto Varas, Abstr vol 1, pp 326-330

Rabbia OM, Hernández LB, King RW, López-Escobar L (2002) Discussion on "Giant versus small porphyry copper deposits of Cenozoic age in northern Chile: adakitic versus normal calcalkaline magmatism” by Oyarzún et al. (Mineralium Deposita 36:794-798, 2001). Miner Deposita 37:791-794

Reynolds JH, Jordan TE, Johnson NM, Damanti JF, Tabutt KD (1990) Neogene deformation of the flat-slab subduction segment of the Argentine-Chilean Andes: Magnetostratigraphic constraints from Las Juntas, La Rioja province, Argentina. Geol Soc Am Bull 102:1607-1622

Richards P (2002) Discussion on "Giant versus small porphyry copper deposits of Cenozoic age in northern Chile: adakitic versus normal calc-alkaline magmatism" by Oyarzún et al. (Mineralium Deposita 36:794-798, 2001). Miner Deposita 37:788-790

Rivano S, Sepúlveda P (1991) Carta Geológica de Chile 69: Hoja Illapel, Región de Coquimbo. $132 \mathrm{pp}$

Sawkins FJ (1990) Metal deposits in relation to plate tectonics. 2nd edn. Springer, Berlin Heidelberg New York, $461 \mathrm{pp}$

Sajona FG, Maury RC (1998) Association of adakites with gold and copper mineralization in the Philippines. C R Acad Sci Paris 326:27-34

Schultz F (1997) Geologie und Geochemie der Copper PorphyryLagerstätte Los Pelambres/Chile. MSc Thesis, TU Clausthal, $89 \mathrm{pp}$

Serrano L, Vargas V, Stambuck V, Aguilar C, Galeb M, Holmgren C, Contreras A, Godoy S, Vela I, Skewes MA, Stern CR (1996) The Late Miocene to Early Pliocene Río Blanco-Los Bronces copper deposit, central Chilean Andes. In: Camus F, Sillitoe RH, Petersen R (eds) Andean copper deposits: new discoveries, mineralization, styles and metallogeny. Soc Econ Geol Spec Publ 5, pp 119-130

Sen C, Dunn T (1994) Dehydration melting of a basaltic composition amphibolite at 1.5 and $2.0 \mathrm{GPa}$ : implications for the origin of adakites. Contrib Mineral Petrol 117:394-409

Sillitoe RH (1973) Geology of the Los Pelambres porphyry copper deposit, Chile. Econ Geol 68:1-10

Sillitoe RH, Gappe, IM Jr (1984) Philippine Porphyry Deposits: Geologic settings and characteristics. In: United Nations Economic and Social Commission for Asia and the Pacific, Bangkok, CCOP Technical Publication pp 14-89

Skewes MA, Stern CR (1994) Tectonic trigger for the formation of late Miocene $\mathrm{Cu}$-rich breccia pipes in the Andes of central Chile. Geology 22:551-554

Skewes MA, Stern CR (1996) Late-Miocene mineralized breccias in the Andes of central Chile: Sr- and Nd-isotopic evidence for multiple magmatic sources. In: Camus F, Sillitoe RH, Petersen R (eds) Andean copper deposits: New discoveries, mineralization, styles and metallogeny. Soc Econ Geol Spec Pub 5:33-41

Stern CR (1991) Role of subduction erosion in the generation of Andean magmas. Geology 19:79-81

Stern CR, Futa K, Muehlenbachs K (1984) Isotope and trace element data for orogenic andesites from the Austral Andes. In: Harmon RS, Barreiro BA (eds) Andean magmatism: chemical and isotopic constraints. Shiva Publishing, Cheshire, pp 31-46

Stern CR, Skewes MA (1995) Miocene to present magmatic evolution at the northern end of the Andean Southern Volcanic Zone, central Chile. Rev Geol Chile 23:39-52

Stern CR, Kilian R (1996) Role of the subducted slab, mantle wedge and continental crust in the generation of adakites from the Austral Volcanic Zone. Contrib Miner Petrol 123:263-281

Thiéblemont D, Stein G, Lecuyer JL (1997) Gisement épithermaux et porphyriques: la connexion adakite. CR Acad Sci Paris Sci Terre Planèt 325:103-109

Titley SR, Beane RE (1981) Porphyry copper deposits, part1: geologic settings, petrology and tectogenesis. Econ Geol 75:214-269

Yáñez G, Ranero C, von Huene R, Díaz, J (2001) Magnetic anomaly interpretation across the southern central Andes (32$\left.34^{\circ} \mathrm{S}\right)$ : The role of the Juan Fernández Ridge in the late Tertiary evolution of the margin. J Geophys Res 106:6325-6347

Yáñez G, Cembrano J, Pardo M, Ranero C, Sellés D (2002) The Challenger-Juan Fernández-Maipo major tectonic transition of the Nazca-Andean subduction system at $33-34^{\circ} \mathrm{S}$ : geodynamic evidence and implications. J S Am Earth Sci 15:23-38 